\title{
A place in the sun? Discursive constructions of positive outcomes in post-migration stories in the Algarve
}

\author{
Kate Torkington ${ }^{1}$ and Filipa Perdigão Ribeiro \\ Universidade do Algarve, Escola Superior de Gestão, Hotelaria e Turismo, \\ Campus da Penha, 8005-139 Faro, Portugal.
}

\begin{abstract}
This study argues for more comparative research between seemingly different migrant groups, bringing a new focus on intra-European migration in Portugal by examining and comparing the reasons why migrants from different geographical origins choose to settle in the tourism-based Algarve region. Drawing on data collected from a questionnaire survey and interviews, the study first compares the profiles of two apparently distinct migrant groups - Northern and Eastern Europeans - and goes on to explore their discursive representations of migration experiences. Findings reveal that despite differences in initial motivations for moving to the Algarve, there are similarities between the two groups in terms of what leads them to settle in the region. Among both groups there is a high level of positive place-identity, suggesting that the specific context of the destination place plays a significant role in positive post-migration outcomes, something which is often overlooked in migration studies. Furthermore, the lived and perceived lifestyle affordances of the destination place, especially when discursively compared with the place and lifestyle left behind, are flagged by both groups and lend support to the idea that the role of lifestyle in migration has a wider significance than is usually credited.
\end{abstract}

Keywords: intra-European migration; positive outcomes; lifestyle; placeidentity; the Algarve; discourse

\section{Introduction}

Climate was the reason for me to stay at the Algarve - no other reasons. And to be honest, that is the reason for most of my friends here. They are mostly expats and want to stay here as long as possible (Elke, German, retired).

It's like every foreigner says it's the sun, the people are very calm, and of course the climate is very pleasant [laughs] I can't imagine what it was like to spend winter in the Ukraine and the food, everything is fine [...] it's great to live here (Yulia, Ukrainian, self-employed $)^{\mathrm{i}}$

These short excerpts are taken from interviews with migrants currently living in the Algarve, southern Portugal, who describe in strikingly similar terms why they have settled in the region: the sunshine and pleasant climate have played a significant role. This is unsurprising in the case of Elke, a German who, like many of her 'expat' friends and compatriots, has sought out a 'place in the sun' in which to enjoy a leisurely lifestyle in her retirement; she may indeed be thought of as the archetypal 'international retirement migrant' (King, Warnes, \& Williams, 1998) moving from the north to the south of Europe. On the other hand, the words of Yulia, from the Ukraine, who has been running her own small sewing business for the past few years in the Algarve, are not so

\footnotetext{
${ }^{1}$ Corresponding author. Email: ktorking @ualg.pt
} 
predictable, for in the first instance, Yulia might seem rather to represent the so-called 'economic migrants' from eastern Europe who move to the west of Europe in search of work opportunities. Yet for Yulia, along with apparently 'every foreigner', it seems that the climate and the overall quality of life are strong factors in her decision to settle in the region, especially compared to life in the country left behind.

The main aim of this study is to explore which factors, according to migrants' own accounts, contribute to successful, positive outcomes in intra-European migration to the Algarve: in other words, what leads people from both the north and the east of Europe to settle in the region, whatever their initial motivations for the move may have been. Despite the growing indications that Portugal is one of the 'least attractive' destination countries for current intra-European migration trends (Pires, 2015) - perhaps due in part to its peripheral geographic position in Europe but also to the fact that it has been one of the most severely affected EU countries in terms of the recent economic crisis - it does not appear to be the case that European migrants are leaving the country in large numbers, as has happened in the context of Spanish coastal provinces, for example (Huete, Mantecón, \& Estevez, 2013). Although since the onset of the crisis numbers of foreign nationals residing in the Algarve have dropped from their peak in 2009, there has by no means been a mass exodus. In fact, there is plenty of evidence that people of various European origins are choosing to settle in this region on a long-term basis.

Recent inward migration to this region is clearly directly connected to tourism - the Algarve is Portugal's most important tourist destination - meaning that the migration context is quite different from that of large cities or industrialised areas. On the one hand, the Algarve has, for the past decades, been a popular destination for what has variously been termed 'international retirement migration' (e.g. King, Warnes, \& Williams, 1998); 'residential tourism' (e.g. Huete, Mantecón, \& Mazón, 2008), or 'lifestyle migration' (e.g. Benson \& O'Reilly, 2009) - i.e. the north-south international movement of relatively affluent individuals to make the most of the lifestyle affordances provided by, among other aspects, the more agreeable climate, the geographical features, and the tourist infrastructures and facilities already in place. On the other hand, tourist destination regions such as the Algarve also offer employment and business opportunities, particularly in the construction industry and in the service sector, and this makes them attractive destinations for relocation for those who do not have the economic resources to lead a primarily leisure-based post-migration lifestyle. So-called 'economic migrants' from the east of Europe (Malheiros \& Esteves, 2013) have in fact been arriving, living and working in this Portuguese region in relatively large numbers for well over a decade, also initially attracted by the 2001 immigration law which granted 'permits of stay' for any immigrant with an employment contract. In fact, the majority of immigrants during the last years of the twentieth century were from Eastern European countries such as the Ukraine, Moldova, Romania, and the Russian Federation (Teixeira \& Albuquerque, 2015). ${ }^{\text {ii }}$ Yet to date there is a lack of research into this particular socio-geographic context of migration, in particular at the micro level, with most studies focusing on large-scale demographic trends or their political framing (Favell, 2008).

However, one of the main considerations underlying the research presented here is that whatever might initially attract migrants to a particular destination area - in other words motivations or reasons for moving - is not necessarily what leads them to stay on a long-term basis. It is generally argued nowadays that migration is a process rather than a one-off move or event (e.g. de Haas, 2010; O'Reilly, 2012; 2016), yet it does seem that migrants are still often conceptualised, across various social fields of action (the media, political and social institutions, academia), as belonging to groups that are defined by their initial motivations for moving as well as the place of origin of their migration 
trajectory. Our findings suggest that settlement in the Algarve region is due in large part to the perceived lifestyle affordances of this particular place, leading us to reflect on the role of lifestyle and place across what have generally been considered as distinct 'types' of migrants: those arriving from the north of Europe and those from the east.

A further aim of this paper, then, is to investigate the interrelationships between place and migrant identities. Since social identities are not easily separable from placemaking activities, for "place and self help construct and activate each other" (Sack, 1997, p. 132), we take the approach that this dialectical relationship is encapsulated in the concept of place-identity. Although the relationship is complex, we make the assumption that it is articulated in and through discourse, since both place and self are ascribed meanings and identities in large part through discursive practices, in both public and private spheres.

\section{The role of lifestyle in migration}

The study of lifestyle migration was originally conceptualised as a framework that focuses on the migration of the 'relatively affluent and relatively privileged' (Benson \& O'Reilly, 2009; 2016). The processual nature of this kind of migration has certainly been well addressed in the literature, with ample discussion of the complex, shifting, character of post-migration experiences, aspirations and identities, often illustrated through rich and detailed ethnographic studies. However, one potential problem is that in order to 'qualify' as a participant in such a study, the 'motivational' factor of lifestyle must have been there in the first place, therefore excluding the possibility of studying migrants for whom lifestyle considerations were not initially present but have become increasingly evident after spending some time in a migration destination place.

This has meant that the analytical lens of lifestyle migration has mostly been applied in research sites where there has been an obvious flow of migrants from a country or countries of origin that are generally considered to be more economically developed than the country of destination, and for whom economic factors do not therefore appear to have played a major role in their decision to move. As such, there are a wide range of studies, from varying perspectives, of northern Europeans in southern Europe (e.g., inter alia, Åkerlund \& Sandberg, 2015; Casado-Diaz, Kaiser \& Warnes, 2004; Gustafson, 2008; Kordel, 2016; O'Reilly, 2000; Torkington, 2012) or North Africa (e.g. Escher \& Petermann, 2014; Therrien \& Pellegrini, 2015) as well as North Americans in South American destinations (e.g. Benson, 2013; Croucher, 2012; Hayes, 2015); 'Westerners' in India (Korpela, 2010) or south-east Asia (e.g. Botterill, 2016; Green, 2014). Thus, although as Benson and O'Reilly (2016) emphasise, the original conceptualisation of lifestyle migration was never intended "to identify, demarcate and define a particular group of migrants" (p.21), in fact the burgeoning lifestyle migration literature, perhaps unavoidably, seems to have done just that. Therefore, as Benson and O'Reilly (2016, p. 33) note, it is both timely and important "to think about the role of lifestyle in migration more generally", as well as "the opportunities and structures that support and hinder this".

At the same time, much of the literature in migration studies side-lines or simply ignores these more privileged migrations, and tends to focus on other types of migrants notably those motivated by economic factors - and thus reinforces the identity labels that ultimately divide migrants into categories, intentionally or otherwise. As Croucher (2015, p. 169) argues, whilst it is important to highlight the power asymmetries between lifestyle migrants and other types of migrants, the common ground between them should not be ignored, for "[s] hould those similarities be obscured, then the privilege of the former is in a manner preserved and problematic stereotypes of the latter are perpetuated". 
From an intra-European perspective, it is perhaps surprising that there have not been more comparative analyses of different groups of migrants, given that the socio-economic geographies of Europe are clearly shifting and the issue of 'relative privilege' is by no means a clear-cut concept. Many of the CEE (Central-East Europe) countries labelled as 'transition economies' by the IMF in 2000 are now considered to be 'post-transition' or even, in the case of the Baltic States, to have joined the 'advanced economies' of Europe (Niklova \& Graham, 2014). On the other hand, many EU countries, especially those in southern Europe, have been severely impacted by economic crisis since 2009. Yet despite repeated calls for more comparative analysis among migrant groups, between and within different destination places (e.g. King, 2002; 2012), this type of research is very scarce.

We set out in this study, therefore, to begin to scrutinise what Croucher (2015, p. 167) calls the "under-investigated and potentially promising" comparisons between lifestyle migration and labour, or economic, migration. Specifically, we explore what leads migrants to settle in the Algarve region and to what extent this decision is actively based on perceived 'success' or positive experiences rather than, say, a perceived lack of other options. In this way, we hope also to shed some light on what we might term 'successful outcomes' in migration. Whilst such outcomes may be primarily grounded in individual stories, it is important to note that outcomes in migration are related to various layers of external structures as well as to individual everyday practices and experiences, and therefore all these aspects of migration stories (along with the interactions among them) need to be taken into account when investigating outcomes (O'Reilly, 2012, p. 32). The external structures, or macro conditions, that frame migration should be carefully examined at both the global level and at the more proximate, local level, since the laws, policies, institutional and organizational practices, socio-economic climate and historical context of both originating and destination areas all have an influence on creating constraints and opportunities for specific migration trajectories. In this way, we take into account the 'double embeddedness' of migration (King, 2002, p. 101): at the micro-level, the embeddedness in individual life-courses and at the macro-level, the embeddedness in the societies and socio-spatial processes of the places in question.

We begin our case study, therefore, by sketching out the macro-level context of migration to the Algarve. Then, after a brief discussion of what might constitute 'successful' or 'positive' post-migration outcomes, we take as an empirical starting point the geographically-based distinction of 'northern' and 'eastern' European migrants. As discussed above, these two groups tend to be empirically studied as 'lifestyle' and 'economic' migrants, respectively. Data from a questionnaire we conducted among European ${ }^{\text {iii }}$ migrants in the Algarve allows us firstly to profile and compare the two groups on several levels. Then, from an analysis of the discursive repertoires used in talk about positive migration experiences, we go on to show that although there are differences between the two groups, there are indeed similarities in how their post-migration lives are discursively constructed and perceived; particularly that on-going lifestyle considerations are tantamount to positive outcomes across both groups. We conclude that for the most part, these similarities are place-based, and thus argue for a framework for evaluating post-migration outcomes that pays greater attention not only to lifestyle, but also to the significance of the destination place and the evolving construction of place-identity.

\section{Migratory flows to Portugal and the Algarve}

Until the late twentieth century, Portuguese migratory flows were characterised by mass outward migration. Since the Age of Discoveries and subsequent period of colonialization, Portuguese people have emigrated to places across the globe, in large 
numbers. Between the mid-nineteenth and mid-twentieth centuries, over a million Portuguese emigrated to the Americas (Baganha, 1991), particularly to Brazil. Around the mid-twentieth century, at a time when, politically, Portugal was all but isolated from the rest of Europe due to the Estado Novo dictatorship regime, emigration to other European countries (in particular France, but also Germany, Luxembourg, Switzerland) became a social phenomenon that deeply affected Portuguese society, with a further 1.2 million Portuguese leaving the country - many clandestinely - during the 1960s alone (Vieira \& Trindade, 2008). However, after the Portuguese Revolution in 1974, which led to stable democracy and the independence of the Portuguese African colonies, emigration decreased dramatically and a steady flow of incoming migration started from the former colonies.

By the beginning of the twenty-first century, there was also a notable reverse in the intra-European migration flows (Peixoto, 2014), with Portugal becoming a 'new' destination country for two main types of European migrants, who have come to be defined in academic discourse by both their motivations and geographical region of origin: the 'lifestyle migrants', or 'residential tourists', from northern European countries $^{\text {iv }}$ and the 'economic' migrants from eastern Europe. The Algarve is evidently a favoured destination for both these groups of migrants, being the second most sought out region in Portugal after Greater Lisbon (SEFSTAT, 2013).

On the one hand, the Algarve has seen a growing increase in the north-to-south migration phenomenon in Europe which is both tourism-informed (Williams \& Hall, 2000) and consumption-led, and fits within the framework of contemporary 'lifestyle mobility' (Cohen, Duncan, \& Thulemark, 2013). Although numbers are difficult to ascertain, since EU citizens are not obliged to register their residential status, it has been estimated that in the early twenty-first century, around 40,000 Britons alone were living in the region on a part-time or full-time basis, a figure equivalent to almost $10 \%$ of the regional population. Although many northern Europeans correspond to what Åkerlund and Sandberg (2015) have termed 'lifestyle movers', i.e. retirees who move seasonally between at least two countries, many more have made the Algarve their principal, and often sole, place of residence.

Since the turn of the century, there has also been an influx of migration to the Algarve from eastern Europe - especially from the Ukraine, Romania and Moldova. This can also be considered tourism-related, as it was the lure of jobs directly or indirectly related to the tourism sector that was the initial magnet. The first (mostly male) job-seekers were soon joined by their families, and communities quickly built up as a result of chain migration. The numbers of foreign nationals originating from eastern European countries steadily increased, reaching a peak in 2009. With the unfolding economic crisis in Portugal, however, which quickly led to high levels of unemployment, ${ }^{\mathrm{v}}$ failing businesses (many of which were related to the tourism sector) and imposed austerity, the official number of incoming migrants has been dropping since 2009 (SEF [Immigration and Borders Service], 2014), although this decrease also reflects the acquisition of Portuguese citizenship by many migrants (Peixoto, 2014). In fact, it is certainly not the case that the Algarve has witnessed a mass exodus of European migrants over the past few years. On the contrary, many people have stayed put. According to the official 2013 Immigration Services Report (SEF, 2014), almost 60,000 foreign nationals were living in the Algarve, equivalent to around $13 \%$ of the regional population, well above the $4 \%$ of the national population. Moreover, a large proportion of the region's foreign population originate from other EU member states, and therefore, as mentioned above, are not necessarily visible in the official population statistics. ${ }^{\mathrm{vi}}$ 


\section{Perspectives on positive outcomes in migration}

Machado and Azevedo (2009, p. 27) have pointed out that it is the relatively under-studied EU migrants in Portugal that represent the "socially successful" migrants. In fact, 'successful' or positive outcomes in migration are generally given less attention than unsuccessful, or problematic outcomes. The concept of 'success' in migration can be understood from two main perspectives. On the one hand, in a more 'objective' social sense, it could be linked to the societal contribution of migrants - for example through economic contributions in the form of paying taxes, supporting local economies through consumption practices, or even through 'foreign investment' in the region: buying upmarket properties or starting business enterprises. It has been noted in the literature that 'lifestyle migrants' are seen as 'desirable' migrants for these reasons (Torkington, 2014) and in some destination regions (including Portugal) there are fiscal incentive schemes in place to target and attract more such migrants (Åkerlund, Lipkina \& Hall, 2015; David, Eimermann \& Åkerlund, 2015). Therefore, for the Algarve, the increasing numbers of such migrants settling in the region might well be considered as a 'successful outcome' both by and for the local community.

In contrast, in many places throughout Europe, the arrival and settlement of large numbers of eastern European migrants might not be perceived so positively, since the discursive repertoires circulating in the mass media and in local and national politics often reinforce negative socio-economic impacts of such migrants, e.g. as 'being a burden on the state' or 'stealing jobs from local people'. Such repertoires are more predominant in countries that are witnessing a sharp rise in both far-right nationalist extremism and euroscepticism, such as Austria (Kraler \& König, 2014), the Netherlands (Bonjour \& Scholten, 2014), and the UK (Düvell \& Vollmer, 2014). Whilst this is not so blatantly the case in Portugal, there are nevertheless some rather negative discourses circulating about eastern European migrants; for instance, in the Algarve they have been associated with a perceived increase in (particularly violent) crime. A wide-ranging study conducted in 2010 on the attitudes of Portuguese people to immigration and immigrants (António, 2011) found that respondents showed a higher level of prejudice towards eastern European immigrants than towards African or Brazilian immigrants; northern Europeans were noticeably absent from the categories of immigrants used in the survey, once again showing that they are not viewed as 'immigrants'.

On the other hand, success can be perceived in a much more individualistic or subjective way, with migrants measuring their own post-migration success by evaluating, for example, their levels of happiness, well-being, quality of life, or personal wealth in comparison to what they experienced in their lives before the move, or by comparing themselves to others (e.g. people in their country of origin). Studying positive outcomes from this perspective may involve exploring different facets of migration experiences and outcomes, such as social capital, i.e. the social relationships, social contacts and network connections they build in their destination place (e.g. M.A. Casado-Díaz, A.B. CasadoDíaz, \& J.M. Casado-Díaz, 2014; Ryan, Sales, Tilki, \& Siara, 2008), reported levels of happiness and wellbeing (e.g. Bălţătescu, 2007; Bartram, 2013) or the absence of psychological stress (Lerner, Kertes, \& Zilber, 2005).

Such studies are often based on sociological or psychological models which use quantitative methods in order to try to measure levels of success or related concepts. In our study, however, we take a more qualitative approach, focusing on how relatively settled migrants discursively construct and perform the outcomes of their migration process in terms of individual criteria for success. We therefore add to the growing body 
of literature that places migrants centre stage in the explanations of their experiences by examining their narrative accounts (e.g. Åkerlund \& Sandberg, 2015; Datta et al., 2009; Lulle \& King, 2016) as well as locating these narratives in their specific socio-geographic setting, and thus exploring to what extent criteria for individual 'success' stories are embedded in place-specific contexts. The most suitable methodology for researching this process involves 'giving voice' to migrants and thus focusing on migrants as "interpretative subjects of their own mobility" (Silvey \& Lawson, 1999, p. 126), rather than seeking to objectify them to fit with a particular perspective on migration, or indeed with a particular 'type' of migrant.

At the same time, it is important to note that what is said in a research interview is "not a wholly original, unique production for that occasion" (Taylor, 2010, p. 6). Rather, speakers tend to draw on ideas (and the means of expressing them) which are part of the discursive resources of a particular social group or society, and thus they might be reiterating ideas which are in broader circulation in their particular socio-cultural context. It can therefore be assumed that certain 'repertoires' may be identified in migrants' talk that are not merely (or wholly) individual viewpoints, but are also indicative of shared ideas among a social group. In this way, talk about (post)migration experiences is simultaneously constituted by and constitutive of both individual and collective social identities and positionings.

\section{Overview of the study}

This paper draws on data collected from a questionnaire survey, interviews and ethnographic observation. The purpose of the questionnaire survey (conducted in 2012) was to obtain 'profiling' data, including socio-demographic data (age, nationality, place of residence, education; employment status), reasons for choosing the Algarve as a destination, length of time living in the Algarve, and intention to stay in the foreseeable future. Data were collected through questionnaires made available in four languages (Portuguese, English, Romanian and Ukrainian). The questionnaire was advertised on social media and by emailing various local associations and organisations which have close ties to the migrant communities in the Algarve. We also sent the questionnaire to various personal contacts asking them to pass it on to friends and acquaintances, using a snowball sampling technique. Although the sample is therefore non-probabilistic, the questionnaires collected were fairly representative of the distribution of the foreign population in the Algarve by municipality of residence. Figure 1 shows a map of the Algarve region according to its division into 16 municipalities and the percentage of respondents (bars in orange) side by side with the percentage of foreign-born inhabitants from each municipality (bars in yellow). 
Figure 1. Map of the Algarve with distribution of respondents and total foreign residents per municipality

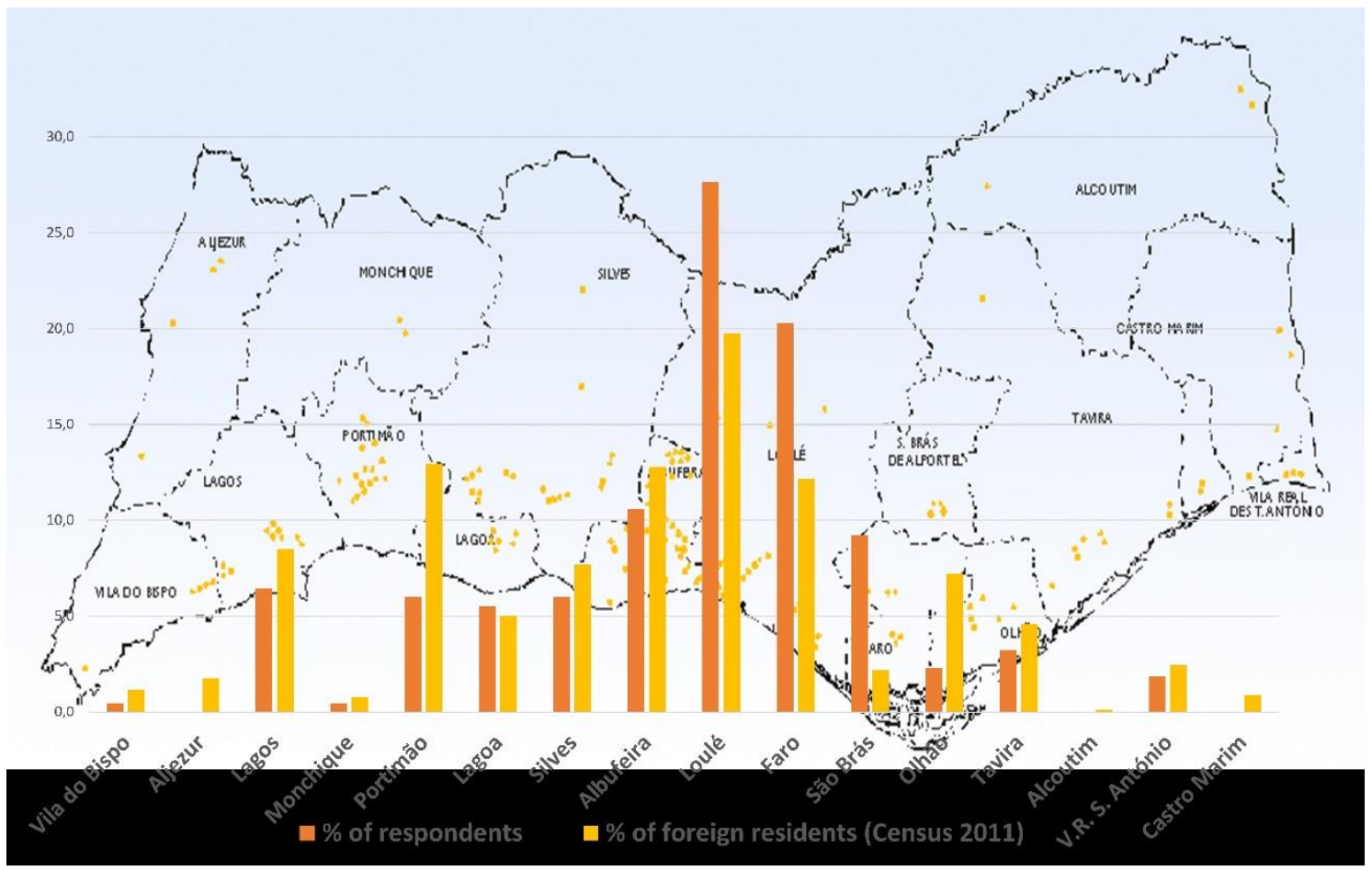

Although the sample included 18 nationalities, for the purposes of this paper we focus on the European sample ( $\mathrm{n}=198$ and 13 nationalities) which we divided into two groups defined as northern and eastern Europeans, hereafter NEs and EEs (see table 1). The data analysis conducted was merely descriptive, since we aimed to briefly compare the profiles of the two groups.

Table 1. NE and EE respondents, by nationality and gender

\begin{tabular}{|c|c|c|c|}
\hline Nationality & No. respondents & Male & Female \\
\hline UK & 59 & 24 & 35 \\
\hline Netherlands & 9 & 2 & 7 \\
\hline Germany & 7 & 2 & 5 \\
\hline France & 6 & 3 & 3 \\
\hline Ireland & 2 & 0 & 2 \\
\hline Denmark & 1 & 0 & 1 \\
\hline Sweden & 1 & 0 & 1 \\
\hline Switzerland & 1 & 0 & 1 \\
\hline Total Northern Europe & 86 & 31 & 55 \\
\hline
\end{tabular}




\begin{tabular}{|c|c|c|c|}
\hline Romania & 46 & 18 & 28 \\
\hline Ukraine & 33 & 15 & 18 \\
\hline Moldova & 23 & 9 & 14 \\
\hline Bulgaria & 8 & 2 & 6 \\
\hline Hungary & 2 & 0 & 2 \\
\hline Total Eastern Europe & 112 & 44 & 68 \\
\hline
\end{tabular}

We also draw on data from two types of interviews with migrants: both in-depth, face-to-face interviews, aimed at eliciting loosely narrated migration story, and shorter email interviews, focused more specifically on how migrants construct the parameters of 'successful' or positive outcomes in their post-migration experience. Although some participants were previously known personally to at least one of the researchers, ${ }^{\mathrm{vii}}$ most were recruited through networking, using what is perhaps best described as an 'opportunistic' sampling method (Ritchie, Lewis, \& Elam, 2003). At the same time, the sample can be considered criterion-based, or purposive, in that participants had to satisfy some criteria, namely: 1) to have lived in the Algarve for more than two years (but ideally longer); 2) to consider Portugal as their only current place of residence (thus avoiding seasonal or 'peripatetic' (O'Reilly, 2000) migrants. For the analysis, we draw on data from in-depth interviews with seven NE adults and six EE adults. These interviews were conducted in English (NEs) or in Portuguese (EEs), ${ }^{\text {vii }}$ at a location of the participant's choice.

The email interviews were conducted by sending emails to respondents in the questionnaire survey who had indicated that they would be willing to participate in a further stage of the research and had given contact details to this end. From a total of 54 emails sent out, we received just eight responses. The lack of response is perhaps an indication of how difficult it is to articulate the complexity and nuances of post-migration experiences. Overall, the face-to-face interviews based around a loose topic guide (moving to and settling in the Algarve, friends, family and community, daily routines and practices, present circumstances), which tried to emulate as far as possible 'natural' talk, was the most successful technique for eliciting data for this study.

The interview transcripts and email texts were subsequently analysed and coded for discursive repertoires which seem to relate directly or indirectly to successful outcomes in post-migration lives. 'Discursive repertoires' can be understood as the smaller units or building blocks of situated language-in-use, which together make up a discourse, which van Leeuwen (2009, p.144) defines as "a socially constructed way of knowing some aspect of reality". Repertoires can also be thought of as conversational resources, shared by particular social groups or communities, which are drawn upon in everyday interaction and can be identified as occurring repeatedly within a group in relation to a particular topic, without necessarily forming a single coherent discourse. In our data analysis, therefore, we looked for evidence of repertoires that seem to circulate in order to make sense of the process of settling in the Algarve. We were able to identity repertoires that seemed to broadly match what we have repeatedly heard in informal conversation with 
and among European migrants in the Algarve, thus we are also situating our data in a more ethnographic approach in which we draw on many years of observations in the field.

\section{Migrant profiles}

Based on our questionnaire survey results, we identified some differences and also some overall similarities between the two groups. Although the EE group has a younger average age than the NE group ( 37 years and 58 years respectively), it is by no means the case that all NEs living in the Algarve are retirees, or living by 'independent means', although this is often depicted as being the case in public discourse. We found that there are many NE residents who are in fact 'currently working' (42\%), although they tend to be selfemployed or running their own business ( $25 \%$ of the NE group), primarily in the tourism and service sector. The growing number of northern European migrants has led to opportunities for a whole range of 'support' services, provided by northern Europeans, principally for their compatriots. A perusal of the services and businesses advertising in the classified sections of the local English-language press shows that there is certainly no shortage of British, German and Dutch architects, beauticians, builders, carpenters, caterers, dog trainers, estate agents, financial advisors, gardeners, hairdressers, handymen, health practitioners, lawyers, plumbers, translators, and so the list goes on.

Whilst just over $50 \%$ of EE respondents are employed by others (sometimes, in fact, by NEs), there seems to be an increasing tendency towards self-employment (16\% of our EE group). It seems that the trend towards 'entrepreneurial' migration is also reflected in this group. The type of small businesses run by EEs appearing in the Algarve include small-scale construction and property maintenance, gardening services, cleaning and domestic services, small transport companies, hairdressing salons, sewing services, cafés and grocery stores. Whilst some of these services are clearly aimed at compatriot clients (e.g. shops selling Romanian or Ukrainian food products), other businesses are thriving by targeting not only the Portuguese local community but also the wealthier sections of the NE communities.

In both groups, $28 \%$ of respondents state they are 'not currently working'. ix Although child-care arrangements (primarily stay-at-home mothers) account in part for this, it is more likely to mean non-voluntary unemployment for EEs, whilst for many NEs it is a lifestyle choice, enabled by having sufficient personal funds not to need to work.

The survey points to both groups being relatively well-educated, with almost $40 \%$ of EEs and $60 \%$ of NEs having had some kind of further or higher education which could point to levels of social and cultural capital that would help to achieve successful outcomes in migration.

Motivations for migrating to the Algarve were accounted for by listing a range of reasons and asking respondents to select up to three options in answer to the question 'Why did you choose to move to the Algarve?'. The reasons given for choosing to move to Portugal are, on the one hand, in line with the migrant categories generally associated with NEs and EEs. The northerners tended to select reasons related to lifestyle considerations ('lifestyle'; 'I like the Portuguese way of life'; 'I had been on holiday here before'), whilst the EEs were initially motivated by employment and financial considerations as well as 'lack of opportunities in my own country'. However, it is noteworthy that 'climate' was a highly-cited reason in both groups (first among the NEs and third among EEs, after 'work' and 'lack of opportunities in my own country'). It is also interesting that for many people in both groups the decision was taken by other family members and was often related to the fact that family members or friends were already 
living in Portugal. This suggests that 'chain' migration is not necessarily linked to 'economic' migrants and also that migration amongst northern Europeans is not always entirely voluntary nor, for some, based primarily on individual lifestyle motivations.

The majority of respondents from both groups have been living in the Algarve for quite some time, with 58\% and 56\% of NEs and EEs respectively having lived for more than ten years in the region, indicating relatively stable communities. Furthermore, both groups overwhelmingly reported an intention to stay in the Algarve for the foreseeable future (over $80 \%$ in both groups) along with feeling 'at home' (over $90 \%$ in each group). It was these findings that led us to examine more closely what underlies the process of staying in the region on a long-term basis, and to reflect on whether this diverges from initial motivations.

\section{Settling in the Algarve}

Interviews with individuals from both groups helped us to explore what leads people to stay on in the Algarve after the initial relocation. It is clear that the NEs, who were generally motivated to move to the Algarve due to the perceived lifestyle affordances it offered, continue to give lifestyle-based reasons for settling in the area. Perhaps more surprisingly, EEs also stress the lifestyle they enjoy in the Algarve as a major inducement to stay. Indeed, among both groups there is a high level of positive place-identity - by which we mean the perceived relationships between the self and place(s), as constructed in and through discourse. However, this positive place-identity is constructed in rather different terms. For NEs, it is based on an affective relationship with the attributes and affordances of the place itself, which are often to do with the possibilities for selfdevelopment, or ongoing 'projects of the self' (Giddens, 1991), for example through an active, outdoor lifestyle, as illustrated by the data extracts below:

Moving to the Algarve has provided me with the opportunity to spend more time in outdoor activities, so I now cycle and swim in the sea two or three times per week [...] I'm healthier, fitter and overall happier than at any other time of my life! (Derek, British, retired)

I've become very slow. I'm so laid back now [...] I think I'm a lot more independent, far more independent [...] I'm quite happy to go for a walk on the beach just with the dog or on my own which I really like (Lynn, British, self-employed)

Whilst the EEs we interviewed are also very aware of the physical setting the place provides, including the amenable climate and the opportunities it provides for being outdoors (at the beach, in the park, sitting outside cafés, and so on), they are more likely than NEs to relate to the more social aspects of local place as well. As the following extracts illustrate, social relations which tie one to place and create affective feelings of belonging are highlighted as being essential to positive outcomes:

I've been living in the Algarve since November 2002 and I can say that I feel as if I am at home. I feel integrated, I've raised a family, I have friends and I like what I do (Elena, Moldovan, working)

All my family lives here, parents, brother, my parents-in-law, I've got two children they were born here [...] I've enjoyed living here in Portugal, we're thinking of staying here, 
my kids are Portuguese [...] most of my friends are Portuguese (Irina, Romanian, working)

For NEs, feelings of belonging in place seem to have more to do with the idea of finding and/or creating the perfect home, which generally involves purchasing a property. Property ownership seems to be a fundamental part of settling for lifestyle migrants: certainly, buying the 'ideal' house to fit one's lifestyle requirements and also to create a feeling of belonging in place is something that is often referred to by the NE participants in our study. Many such migrants engage on a trajectory of buying and selling houses, partly for investment purposes and partly in the on-going quest for the ideal home, experimenting with different options (e.g. coastal vs. rural location; modern build vs. restored or traditional style house), as the following excerpt shows:

I've lived in several different places in the Algarve [...] we went from a house in $\mathrm{L}^{* *}$ [a small town] to a village, to an urbanization in $C^{* *}$ [coastal resort town] which is where Andrew was born - that was a very nice house [...] and then we bought an old ruin and the intention was to do it up and make a nice family home [...] and then we bought a plot near $\mathrm{A}^{* *}$ [large coastal resort town] and that didn't work out either actually $[. .$.$] and after that finally we settled on buying a house which we slowly did up$ we renovated over the twelve years that we were there and that was the house that we sold last year $[\ldots]$ and now we've bought a brand new house $[\ldots]$ it's a very pretty house it's in Portuguese style (Samantha, British, self-employed)

The idea of bringing up a family and being able to provide well for them (in terms of material objects, including the physical home) is often referred to by EEs, and although the majority of EEs continue to live in rented accommodation, those who have been in the Algarve for some years are now finding themselves in a position to be able to consider buying an apartment and 'putting down roots' through property ownership:

now I have family here I've got a child, now I want to buy an apartment [...] because my life now is here all my things are here now (Andriy, Ukrainian, self-employed)

On the other hand, many years of careful saving is also seen by some EEs as a means of being able to buy a property 'back home' as an investment for retirement or as a more affective investment in securing a family home even if it is not intended for living in, at least in the near future.

One of the most common repertoires among both groups, and particularly among women, is that of being able to provide better prospects for one's children in Portugal. For EEs, this seems to entail a whole range of opportunities, including educational and material provisions, and this sense of being able to give more to one's children is constructed in contrast to what the situation would have been 'back there':

[the overall balance is] positive I've been able to give my kids everything that I couldn't give them there [in the Ukraine] (Yulia, Ukrainian, self-employed)

For Ukrainians achieving success as an immigrant in Portugal is above all to have wellguided children in school, in gym classes, in dance classes, in art classes, it's that part to be able to give a good foundation for the children (Natalia, Ukrainian, working)

Another aspect that strongly features in the discourse of EE migrants is the relative safety of the environment in the Algarve, especially compared to the places they have left behind, something which again is seen as beneficial for bringing up children. Some of 
our NE respondents who brought children to live in Portugal also stress how life has been better for their children in Portugal, with many referring to the greater amount of freedom they were able to grant them, due to the perceived safety of the place, as well as the opportunity to spend more time outdoors (e.g. at the beach, or the swimming pool). Several women also described how their children had suffered in some way in their schooling 'back home' and how much better the educational experience has been for them in the Algarve, whether attending an International School (where the children are taught in English) or a Portuguese state school. Amanda describes how, even with the added challenge of them having to learn Portuguese 'from scratch', sending her three sons to the local Portuguese school has been an extremely positive experience:

but as far as the schooling went I mean we haven't looked back as far as Chris was concerned he was um borderline dyslexic when we were in the UK and they were having problems with him at school but we think bringing him out here and starting all over again has given him a second chance, in his education and he's doing really really well now (Amanda, British, currently not working)

Although for many EEs, the initial reason for moving to Portugal was to find work, and although for those who do not have other means of income it is tantamount to success to have some sort of relatively stable employment, it does not appear to be the job opportunities in themselves that attract people to settle and stay in the region. Indeed, it can be argued that Portugal offers some of the least attractive employment opportunities in western Europe in terms of salaries and job stability. Yet despite the current high unemployment rates, the majority of EEs living in the Algarve do not seem to have problems finding work, often in tourism-related service jobs (for women) and construction or related semi-skilled jobs (for men). In the same way as there are NEs in the Algarve for whom work is a means to an end, i.e. gaining a better quality of life and a more fulfilling way of life, EEs also seem to be settling in the Algarve for similar reasons:

I like living here. Life is calm I don't have any problems [...] I'm not here just because of work... I'm here because I like the way of life, in our country life is harder more dangerous... here everything is very calm I like that... I like being here (Ion, Moldovan, working)

The 'calmer' and more peaceful way of life in the Algarve, in comparison to the country of origin, is in fact a discursive repertoire common to both groups, although for EEs it is constructed as being compared to a 'harder' and 'more dangerous' way of life back home, with an emphasis therefore on safety and security, whilst for NEs the contrast is usually with the 'rat-race' and the 'regimented' way of life, thus highlighting the sense of freedom from constraints - a repertoire often associated, indeed, with tourism practices:

Everything was more regimented than here and I had a more regimented life everything was to the clock whereas here [...] I just think no, let's go, you know the sun's shining, it's warm let's- you know let's get out there (Jean, British, retired)

The representations of the Algarve that emerge from the talk of the NE participants are generally set up as rather vague, stereotypical positive evaluations of the 'here' place ('it's so lovely/relaxed/laid-back/friendly here') and its lifestyle affordances, in direct contrast with negative evaluative representations of the place left behind and its oppositional lifestyle constraints These generally transpire as both behavioural affordances, such as being able to spend more time and to do more activities outdoors, as 
well as relational affordances such as spending more 'quality' time with family and friends; health and well-being affordances such as a better diet, and often better healthcare possibilities, and in general the possibility for a more 'simple' way of life. It is noteworthy that the economic affordances such as the lower cost of living, niche business opportunities, tax relief and 'trust' schemes, are rarely referred to in the interviews, although the local English-language media certainly consistently flag these benefits. The repertoires depicting the negative 'constraints' of the lifestyle left behind include: being 'stuck indoors'; having no time for one's friends and family; the abundance of processed, unhealthy food and sedentary lifestyles; the decline of the National Health system (in the UK); the 'extortionate' cost of living; the social competitiveness, the obsession with consumption, and so on.

For the EEs, the direct comparisons of the way of life between the 'here' and 'there' places are rather different. The perceived 'freedom' and 'peacefulness' of life in the Algarve is characterised by reference to the easy-going nature of local people, openness of social life, as well as a genuine appreciation of Portuguese food, particularly that which is cooked and eaten outdoors, which most interviewees mentioned. In fact, the climate is a consistent reference of all EE interviewees, as the enabling factor to the 'freedom' they feel. In contrast, there is frequent reference to the corruption and bribery in the countries left behind, having to take 'gifts' to officials to get things done; the 'stricter' social rules and mentalities and different, more 'limiting' social expectations - especially for young women. As Alina (a young Romanian woman) told us: "there girls get married young... they go to university but when they've finished they get married straight away". In general, life in the Algarve is seen as being much more straightforward and transparent, compared with the 'more complicated' way of doing things 'back there'.

Other common repertoires compared the safe, comfortable life in the small, seaside towns of the Algarve with feeling 'a bit lost' in the big, 'chaotic' towns and cities of eastern Europe. This may indicate at least a degree of allegiance with the counterurbanisation movement - which is usually conceptualised as a search for the 'rural idyll' whereby the countryside is perceived as a 'therapeutic landscape' (Hoey, 2009) and the key to a more fulfilling way of life (Benson, 2010). In these cases, the 'rural idyll' may have been encountered accidently rather than actively sought out, but the perceived benefits from living in such a place are noted nonetheless.

By discursively enacting attachments to the 'here' place through positive representation, the speakers seek to build a positive self-representation as a migrant who is in control of life-choices. As Cresswell (2004, p. 102) notes, the creation of place necessarily involves defining what lies outside. The juxtaposition of here and there is thus a form of 'othering', helping to reinforce the positive status (and identity) of the 'insider' by rejecting what lies on the outside. In much the same way that 'out-group derogation' and 'in-group celebration' are typical socio-psychological (discursive) strategies that can help to define ideological social group membership (van Dijk, 2009), the participants in our research seem to use 'there-place derogation' and 'here-place celebration' as discursive strategies that enable them to build a sense of 'insideness', and therefore as 'belonging' in the Algarve. This relational sense of place - resulting from a critical evaluation of the chosen place of residence as compared to other possible residential places - seems to be a crucial aspect of the mode of belonging that allows people to settle happily in a place. At the same time, these discursive strategies enable a self-positioning which counteracts the collective 'outsider' positioning that is constantly reinforced by the categorisation of people as '(im)migrants'.

\section{Discussion and conclusions}


This study has argued for more comparison between seemingly distinct migrant groups, and at the same time has brought a new focus on intra-European migration in Portugal by comparing how migrants from different geographical origins discursively construct positive post-migration outcomes. Having started by comparing the self-reported profiles of migrants from Northern and Eastern Europe, and having ascertained that most of our research participants felt settled and 'at home' in the region and intended to stay for the foreseeable future, we found that there are indeed some common repertoires in their postmigration stories, namely those related to the way of life that the place affords. This finding lends support to the call for a greater examination of the role of lifestyle in migration processes.

The perceived opportunities and affordances provided by the specific destination place in terms of lifestyle and quality of life are almost always flagged in these stories. It might be pertinent to question at this point what is meant by 'lifestyle', for it is a rather vague term, ultimately subject to individual conceptualisation according to one's values, beliefs, and aspirations. Furthermore, what constitutes an 'ideal' lifestyle or way of life is undoubtedly "context specific, fractured across social groups and nationalities" (Benson and Osbaldiston, 2016, p.14). However, it seems that certain factors (at the micro-level) are consistently associated with what Benson and O'Reilly (2009, p. 610) call "the search for the good life as a comparative project" - a project which entails a "renegotiation of the work/life balance, quality of life and freedom from prior constraints", making it necessary to constantly compare the (lived or imagined) ways of life in different places. Although both 'lifestyle' and indeed 'quality of life' may well be associated with material advantages, whether these might entail personal financial gain, e.g. from employment or business opportunities, or from a lower cost of living, cheaper property prices and fiscal benefits, it is also undoubtedly associated with more intangible benefits which stem from living in a place whose perceived affordances are almost universally recognised as being positive: an amenable and healthy climate (both meteorological and social), a slower pace of life, leisure opportunities and a sense of personal freedom. These kinds of repertoires resonate with typical tourist repertoires, although generally the respondents in our research, in particular the NEs, are concerned to stress the distinction between themselves and the tourist 'other'. Indeed, a temporal aspect is strongly present in the post-migration stories we heard, with frequent references to the amount of time spent living in the Algarve which serves to reinforce a sense of entitlement to being, or belonging, in place as opposed to the transient identities associated with tourists and, indeed, with migrants.

The recurrence of discursive repertoires clearly related to lifestyle in our findings do seem to problematize the categorisations and classifications of 'different types' of migrants so often found in public and, at times, in academic discourse. Huete et al. (2013) have questioned the utility of the concept of lifestyle migration in the Spanish context, arguing that for many NEs, economic factors are increasingly determining the outcomes of their move to Spain, especially since the onset of the European economic crisis. However, our findings may indicate that this also works the other way, since the label of 'economic migrant' is not necessarily suitable for EEs who decide to stay on a long-term basis in the Algarve. Whilst finding (and keeping) employment might be a necessary facet of most migration trajectories from eastern European countries, it seems to be rather the way of life afforded by the place that is the determining factor of choosing to stay on and settle - eastern Europeans in the Algarve repeatedly state that they simply 'like living here' and 'enjoy the way of life', compared not only with their country of origin but also, sometimes, with other European destinations they have previously experienced. Like the NEs, it would seem, they too have found their 'place in the sun'. 
This is not to say, however, that the metaphorical 'place in the sun' is constructed on the same terms. For the NEs, there are distinct post-colonial references: after all, the very phrase is said to come from an infamous quote ("we, too, claim our place in the sun") from a nineteenth-century German parliamentary debate which marked the beginning of the "Weltpolitik" strategy of colonial expansion and continues nowadays to suggest a position of advantage or privilege. Ongoing place-making activities (including discursive practices) in the Algarve certainly position NE lifestyle migrants as a privileged social group, and many of the participants in our study construct place-identities that stress the advantageousness and privilege of their position as residents in Portugal; they present themselves as people who are fortunate enough to live in a place that corresponds to their sought-after lifestyle. Interestingly, the NEs in the Algarve, who are almost never included in any discussion of immigration/immigrants in Portugal, actively choose to call themselves 'residents', often in opposition not only to other 'immigrants' but also to the more mobile and transient 'tourists' ${ }^{\mathrm{x}}$ However, another salient aspect of their collective social identity is grounded in a kind of self-marginalisation; by their apparent refusal to learn the local language and to integrate socially, they seem content to make their own, secluded place in the sun by remaining on the edges of the 'local' society.

There is a clear disparity between the discursive positioning of northern and eastern Europeans in the public sphere. Those who hail from the east are collectively labelled as 'immigrants', and are therefore always, to some degree, positioned as 'outsiders'. It may be, therefore, that their discursive construction of a 'place in the sun' emanates partly from a desire not only to feel more 'inside' the place but also to position themselves as having a more legitimate claim to being 'insiders'. By discursively constructing a positive place-identity - that is, by stressing the 'fit' between themselves, their evolving life stories, their lifestyle expectations and the affordances of their current home-place - they are also able to construct narratives of a positive, successful outcome to their migration decision; one which is not simply viewed in 'economic' or 'labour' terms.

In short, it is clear that there is an inequality in the positionings of different groups of migrants in the Algarve. The northern Europeans are doubly-positioned as privileged, in and through both external discourses and their own talk, whilst the eastern Europeans certainly do not share the privileged status generally conferred on so-called 'lifestyle migrants' by the 'host' population. They must therefore work discursively to construct and project a social identity that positions them more favourably within their socio-spatial environment. It is important to remember that although, as constructive agents, speakers are able to position themselves and project their identities as they choose, they are also 'always already' positioned (Taylor, 2010) by historical and socio-cultural forces, structures and dominant discourses, and therefore all migration stories have a doubleembeddedness in both micro and macro-level contexts.

At a more macro level, then, we may postulate that in many European countries, discourses on (im)migration in the public sphere seem to focus almost entirely on problematic aspects, such as increases in criminality, unemployment, or human trafficking, whereas in Portugal, in general, immigration is not a highly politicised issue and nor has any right-wing political extremism targeting immigration emerged (Peixoto, 2014). It should be noted that Portugal ranked second (after Sweden, out of 38 countries) in both the third (2011) and fourth (2015) editions of MIPEX (Migration Integration Policy Index). ${ }^{\mathrm{x}}$ Recently, the sudden sharp swing back to a negative net migration balance - which can be accounted for by the 'new' wave of young Portuguese emigrants leaving the country in search of employment opportunities abroad - has meant that inward migration is seen by many as a means of boosting a once-again dwindling population. ${ }^{\text {xii }}$ Thus, the constitution of 'positive outcomes' in individual migration stories is framed in 
a general socio-political context of relatively high levels of acceptance and inclusion of immigrants, which, in turn, is reflected in the relatively neutral tone of public and media discourse on immigration to Portugal.

From a governance perspective, our findings may be relevant. Niklova and Graham (2014) argue that studying the levels of well-being and life satisfaction of migrants is important since perceived quality of life and positive affect have beneficial impacts on more macro-level social outcomes, such as public health and labour productivity, in destination countries. Moreover, in the specific case of Portugal, which according to a recent report for the Migration Policy Institute is facing "a demographic time bomb" (Justino, 2016, p.2), it is generally agreed that there is a need to attract more migrants. One way of doing this may be to actively promote the lifestyle affordances and enhanced quality of life that settling in a region such as the Algarve can offer not just for retirees from the north, but also for potential job-seekers from across Europe.

Ultimately, we might wish to question why migrants are so often doubly categorized: according to both their geographical origin and to the factor which might have had most weight in their initial motivation to move, rather than the factors which keep them living in a place. In any case, a more sensitive approach to the study of long-term 'migrant' residents in a particular place involves looking at their ongoing, everyday practices, rather than continuing to focus on past motivations, and, importantly, listening to what people have to say about their relationships with their chosen place of residence. Although positive outcomes in post-migration lives are clearly the result of a number of complex and intertwined factors at various contextual layers, and as such it would be difficult to generalize about what leads to such an outcome, we hope to have shown that the perceived and context-specific lifestyle affordances of the place of residence, and how these feed into the construction of positive place-identities, have an important role to play in the migration stories across many 'types' of migrants. A better understanding of the relationships between migrant groups and specific places, and in particular the role of (spatially-situated) lifestyle and the potential for 'quality of life' that these places can offer, would therefore aid a better understanding of how and why some contexts of migration have more 'successful' outcomes than others, if we are to assume that 'success' in migration is ultimately grounded in settlement rather than mobility.

\section{References}

Åkerlund, U., Lipkina, O., \& Hall, C.M. (2015). Second home governance in the EU: In and out of Finland and Malta. Journal of Policy Research in Tourism, Leisure and Events, 7, 77-97. doi:10.1080/19407963.2014.933229

Åkerlund, U., \& Sandberg, L. (2015) Stories of lifestyle mobility: representing self and place in the search for the 'good life'. Social \& Cultural Geography, 16, 351-370

António, J. H. C (2011). Atitudes face à imigração e aos imigrantes em Portugal [Attitudes towards immigration and immigrants in Portugal]. In J.H.C. António \& V. Policarpo (Eds.), Os Imigrantes e a imigração aos olhos dos portugueses: Manifestações de preconceito e perspectivas sobre a inserção de imigrantes [Immigrants and immigration through the eyes of the Portuguese: Manifestations of prejudice and perspectives on the integration of immigrants] (pp. 37-72). Lisbon: Fundação Calouste Gulbenkian.

Baganha, M. I. (1991). Uma imagem desfocada: A emigração portuguesa e as fontes sobre a emigração [An unfocused image: Portuguese emigration and sources on migration]. Análise Social, 26 (112/113), 723-739. 
Baganha, M., Marques, J.C., \& Góis, P. (2004). The unforeseen wave: Migration from Eastern Europe to Portugal. In M. Baganha \& M.L. Fonseca (Eds.), New waves of migration from Eastern to Southern Europe (pp. 23-40). Lisbon: Metropólis.

Bălţătescu, S. (2007). Central and Eastern European migrants' subjective quality of life: A comparative study. Journal of Identity and Migration Studies, 1/2, 67-81.

Bartram, D. (2013). Happiness and 'economic migration': A comparison of Eastern European migrants and stayers. Migration Studies, 1, 156-75. doi: 10.1093/migration/mnt006

Benson, M. (2010). The context and trajectory of lifestyle migration: The case of the British residents of southwest France. European Societies, 12, 45-64. doi:10.1080/14616690802592605

Benson, M. (2013). Postcoloniality and privilege in new lifestyle flows: The case of North Americans in Panama. Mobilities, 8, 313-330. doi:10.1080/17450101.2013.810403

Benson, M., \& O'Reilly, K. (2009). Migration and the search for a better way of life: A critical exploration of lifestyle migration. The Sociological Review, 57, 608-625. doi: 10.1111/j.1467-954X.2009.01864.X

Benson, M., \& O'Reilly, K. (2016). From lifestyle migration to lifestyle in migration: Categories, concepts and ways of thinking. Migration Studies, 4, 20-37. doi:10.1093/migration/mnv015

Benson, M., \& Osbaldiston, N. (2016). Toward a critical sociology of lifestyle migration: Reconceptualizing migration and the search for a better way of life. The Sociological Review, 64 (3), 407-423.

Bonjour, S., \& Scholten, P. (2014). The Netherlands. In A. Triandafyllidou \& R. Gropas (Eds.), European immigration: A sourcebook (2 ${ }^{\text {nd }}$ ed.) (pp. 261-272). Farnham: Ashgate.

Botterill, K. (2016) Discordant lifestyle mobilities in East Asia: Privilege and precarity of British retirement in Thailand. Population, Space and Place (online version of record, 19 Jan. 2016). doi: 10.1002/psp.2011

Casado-Díaz, M. A., Casado-Díaz A. B., \& Casado-Díaz, J. M. (2014). Linking tourism, retirement migration and social capital. Tourism Geographies, 16, 124-140. doi: 10.1080/14616688.2013.851266

Casado-Díaz, M.A., Kaiser, C., \& Warnes, A. M. (2004). Northern European retired residents in nine southern European areas: Characteristics, motivations and adjustment. Ageing and Society, 24, 353-381.

Cohen, S. A., Duncan, T., \& Thulemark, M. (2013). Introducing lifestyle mobilities. In T. Duncan, S.A. Cohen \& M. Thulemark (Eds.), Lifestyle mobilities: The crossroads of travel, leisure and migration (pp.1-18). Farnham: Ashgate.

Cresswell, T. (2004). Place: A short introduction. Malden, MA: Blackwell Publishing.

Croucher, S. (2012). Privileged mobility in an age of globality. Societies, 2, 1-12.

Croucher, S. (2015). The future of lifestyle migration: Challenges and opportunities. Journal of Latin American Geography, 14, 161-172. doi: 10.1353/lag.2015.0011

Datta, K., McIlwaine, C., Herbert, J., Evans, Y., May, J., \& Wills, J. (2009). Men on the move: Narratives of migration and work among low-paid migrant men in London. Social \& Cultural Geography, 10, 853-873. doi: 10.1080/14649360903305809

David, I., Eimermann, M., \& Åkerlund, U. (2015). An exploration of a lifestyle mobility industry. In K. Torkington, I. David \& J. Sardinha (Eds.), Practising the good life: Lifestyle migration in practices (pp. 138-160). Newcastle: Cambridge Scholars Publishing. 
Düvell, F., \& Vollmer, B. (2014). United Kingdom. In A. Triandafyllidou \& R. Gropas (Eds.), European immigration: A sourcebook (2 ${ }^{\text {nd }}$ ed.) (pp. 363-376). Farnham: Ashgate.

Escher, A., \& Petermann, S. (2014). Marrakesh Medina: Neocolonial paradise of lifestyle migrants? In M. Janoschka \& H. Haas (Eds.), Contested spatialities of lifestyle migration (pp. 29-46). Abingdon, Oxon: Routledge.

Eurostat (2015). Fertility Statistics. Retrieved from http://ec.europa.eu/eurostat/statistics-explained/index.php/Fertility_statistics [accessed 24.09.2015]

Favell, A. (2008). The new face of East West migration in Europe. Journal of Ethnic and Migration Studies. 34, 701-716. doi: 10.1080/13691830802105947.

Giddens, A. (1991). Modernity and self-identity: Self and society in the Late Modern Age. Cambridge: Polity Press.

Green, P. (2014). Contested realities and economic circumstances: British later-life migrants in Malaysia. In M. Janoschka \& H. Haas (Eds.), Contested spatialities of lifestyle migration (pp. 145-157). Abingdon, Oxon: Routledge.

Gustafson, P. (2008). Transnationalism in retirement migration: The case of North European retirees in Spain, Ethnic and Racial Studies, 31, 451-475.

de Haas, H. (2010). The internal dynamics of migration processes: A theoretical inquiry. Journal of Ethnic and Migration Studies, 36, 1587-1687.

Hayes, M. (2015). Moving south: The economic motives and structural context of North America's emigrants in Cuenca, Ecuador. Mobilities, 10, 267-284.

Hoey, B. (2009). Pursuing the good life: American narratives of travel and a search for refuge. In M. Benson \& K. O'Reilly (Eds.), Lifestyle Migration: Expectations, Aspirations and Experiences (pp. 31-50). Farnham: Ashgate.

Huete, R., Mantacón, A., \& Estevez, J. (2013). Challenges in lifestyle migration research: Reflections and findings about the Spanish crisis. Mobilities, 8, 331-348. doi:10.1080/17450101.2013.814236

Huete, R., Mantecón, A., \& Mazón, T. (2008). ¿De qué hablamos cuando hablamos de turismo residencial? [What are we talking about when we talk about residential tourism?] Cuadernos de Turismo, 22, 101-121. Retrieved from http://dialnet.unirioja.es/servlet/articulo?codigo $=2783558$.

INE - Instituto Nacional de Estatística (2012). Estatísticas do Emprego 2012 - 4. ${ }^{o}$ trimestre. [Employment Statistics 2012 - 4th quarter]. Lisbon: INE. Available at http://www.igfse.pt/upload/docs/2013/INEstatisticasEmprego2012.pdf

Justino, D. (2016). Emigration from Portugal: Old wine in new bottles? Washington DC: Migration Policy Institute.

King, R. (2002) Towards a new map of European migration. International Journal of Population Geography, 8, 89-106.

King, R. (2012). Theories and typologies of migration: An overview and a primer. Willy Brandt Series of Working Papers in International Migration and Ethnic Relations 3/12. Malmö: Malmö Institute for Studies of Migration, Diversity and Welfare.

King, R., Warnes, A., \& Williams, A. (1998). International retirement migration in Europe. International Journal of Population Geography, 4, 91-111.

Kordel, S. (2016). The production of spaces of the good life - the case of lifestyle migrants in Spain. Leisure Studies, 35, 129-140.

Korpela, M. (2010), Me, myself and I. Western lifestyle migrants in Varanasi, India. Recreation and Society in Africa, Asia \& Latin America, 1, 53-63. 
Kraler, A., \& König A. (2014). Austria. In A. Triandafyllidou \& R. Gropas (Eds.), European immigration: A sourcebook ( ${ }^{\text {nd }}$ ed.) (pp. 15-27). Farnham: Ashgate.

Lerner, Y., Kertes, J., \& Zilber, N. (2005). Immigrants from the former Soviet Union, 5 years post-immigration to Israel: Adaptation and risk factors for psychological distress. Psychological Medicine, 12, 1805-1814. doi: http://dx.doi.org/10.1017/S0033291705005726

Lulle, A., \& King, R. (2016). Ageing well: The time-spaces of possibility for older female Latvian migrants in the UK. Social \& Cultural Geography, 17, 444-462. doi:10.1080/14649365.2015.1089584

Machado, F.L., \& Azevedo, J. (2009). A investigação sobre imigração e etnicidade em Portugal: tendências, vazios e propostas [Research on immigration and ethnicity in Portugal: Trends, gaps and proposals]. Revista Migrações, 4, 7-31. Retrieved from http://hdl.handle.net/10071/8098

Malheiros, J. M., \& Esteves, A. (2013). Diagnóstico da população imigrante em Portugal: Desafios e potencialidades [Diagnostic of the immigrant population in Portugal: Challenges and potentialities]. Lisbon: Alto Comissariado para a Imigração e Diálogo Intercultural (ACIDI).

Niklova, M., \& Graham, C. (2014) In transit: The well-being of migrants from transition and post-transition countries. IZA Discussion Paper No. 8520. Bonn: Forschungsinstitut zur Zukunft der Arbeit /Institute for the Study of Labor. Available at http://ftp.iza.org/dp8520.pdf

O'Reilly, K. (2000). The British on the Costa del Sol. Transnational identities and local communities. London: Routledge.

O'Reilly, K. (2012). International migration and social theory. Houndsmills: Palgrave Macmillan.

O'Reilly, K. (2016). Migration theories: A critical overview. In A. Triandafyllidou (Ed.) The Routledge Handbook of Immigration and Refugee Studies (pp. 25-33). Abingdon, Oxon and New York: Routledge.

Peixoto, J. (2014). Portugal. In A. Triandafyllidou \& R. Gropas (Eds.), European immigration: A sourcebook ( $2^{\text {nd }}$ ed.) (pp. 287-299). Farnham: Ashgate.

Pires, R. P. (2015). Portugal tem um dos saldos mais negativos da Europa [Portugal has one of the most negative balances of Europe]. Observatório da Emigração, $7 \mathrm{Sept}$. Retrieved from http://www.observatorioemigracao.pt/np4/4542.html

Ritchie, J., Lewis, J., \& Elam, G. (2003). Designing and selecting samples. In J. Ritchie \& J. Lewis (Eds.), Qualitative research practice (pp. 77-109). London: Sage.

Ryan, L., Sales, R., Tilki, M, \& Siara, B. (2008). Social networks, social support and social capital: The experiences of recent Polish migrants in London. Sociology, 42, 672-690. doi: 10.1177/0038038508091622

Sack, R. (1997). Homo geographicus. Baltimore: John Hopkins University Press.

SEF - Serviços de Estrangeiros e Fronteiras (2014). Relatório de imigração, fronteiras e asilo - 2013. [Report on immigration, borders and asylum - 2013]. Lisbon: SEF.

SEFSTAT (2013). Serviço de Estrangeiros e Fronteiras: População estrangeira residente em território nacional - 2013 [Immigration and Borders Service: Foreign population resident in national territory - 2013]. Retrieved from: https://sefstat.sef.pt/distritos.aspx

Silvey, R., \& Lawson, V. (1999). Placing the migrant. Annals of the Association of American Geographers, 89, 121-132.

Taylor, S. (2010). Narratives of identity and place. Hove, East Sussex: Routledge. 
Teixeira, A., \& Albuquerque, R. (2015). Active civic participation of immigrants in Portugal. Country Report prepared for the European research project POLITIS, Oldenburg 2005.

Therrien, C., \& Pellegrini, C. (2015). French migrants in Morocco: From a desire for elsewhereness to an ambivalent reality. Journal of North African Studies, 20, 605-621. doi: 10.1080/13629387.2015.1065044

Torkington, K. (2012). Place and lifestyle migration: The discursive construction of 'glocal' place-identity. Mobilities, 7, 71-92. doi:10.1080/17450101.2012.631812

Torkington, K. (2014). Lifestyle migrants, the linguistic landscape and the politics of place. In M. Janoschka \& H. Haas (Eds.), Contested spatialities, lifestyle migration and residential tourism (pp. 77-95). Abingdon, Oxon: Routledge.

van Dijk, T. A. (2009). Critical discourse studies: A sociocognitive approach. In R. Wodak \& M. Meyer (Eds.), Methods of critical discourse analysis $\left(2^{\text {nd }} \mathrm{ed}\right.$.) (pp. 62-87). London: Sage.

van Leeuwen, T. (2009). Discourse as the recontextualization of social practice: A guide. In R. Wodak \& M. Meyer (Eds.), Methods of critical discourse analysis $\left(2^{\text {nd }}\right.$ ed.) (pp. 144-162). London, Sage.

Vieira, R., \& Trindade, J. (2008). Migration, culture and identity in Portugal. Language and Intercultural Communication, 8, 36-49. doi:10.2167/laic266.0

Williams, A., \& Hall, C. M. (2000). Tourism and migration: New relationships between production and consumption. Tourism Geographies, 2, 5-27. doi:10.1080/146166800363420

${ }^{\mathrm{i}}$ All names and other identifying information have been changed.

ii Fifty-six per cent of these permits of stay were given to Eastern European immigrants (Baganha, Marques, \& Góis, 2004, p.26).

iii It should be noted that we are using 'European' as a geographical construct, except where specifically noted that we are talking about the EU.

iv We use 'northern Europe' from the geographical perspective of a southern European country, i.e. countries to the north of Spain and to the west of Poland and the former 'Eastern bloc'.

$\checkmark$ By the end of 2012, the Algarve had the highest rate of unemployment in continental Portugal, at just under 20\% (INE, 2012: 11)

vi The largest groups of European foreign nationals officially registered as residents in the Algarve hail from: United Kingdom (10,214); Ukraine (8,019); Romania (7,542); Moldova (3,246); Germany (3,245); Holland (2,129) (SEFSTAT, 2013).

${ }^{\text {vii }}$ Both researchers have lived in the region for over twenty years and have a great deal of contact with individuals from both groups in their daily lives, both socially and professionally (i.e. university students and Portuguese language learners and examination candidates) as well as in everyday service encounters and through contacts built up with migrant groups and associations.

viii For the purposes of this paper, all data extracts from EE interviews have been translated into English by the authors.

ix This figure does not include self-reported retirees, who account for $29 \%$ of the NE group but just $1.8 \%$ of the EE group. 
${ }^{x}$ This label is reified amongst this community by the title of long-standing, widely-read weekly English language newspaper, The Algarve Resident.

${ }^{x i}$ For further information, see www.mipex.eu

xii Contrary to countries such as Spain, 95\% of people leaving Portugal in 2013 were Portuguese nationals. In terms of the weight of emigration of nationals, Portugal is currently one of the most affected European countries, along with Slovakia, Romania and Estonia (Pires, 2015). On top of this, Portugal also reported the lowest birth rate in the EU-28 in 2013 (Eurostat, 2015). 